\title{
磁性管ECTの未飽和領域磁化による ノイズ低減数値解析法
}

\author{
学生員 後藤 雄治 (職業能力開発大学校) \\ 正員 橋本 光男（職業能力開発大学校）
}

\author{
Numerical Analysis Simulation of Magnetic Noise Reduction for ECT of Magnetic \\ Tube by Unsaturated Magnetization \\ Yuji Goto, Student Member, Mistuo Hashimoto, Member \\ (Polytechnic University)
}

\begin{abstract}
Eddy Current Testing(ECT) is one of the non-destructive testing methods using electromagnetic phenomena and an effective method for detecting cracks or flaws in conducting materials. ECT can detect internal small cracks in non-ferromagnetic heat exchanger tubes on petroleum plants. In this case differential type probe coils are usually used for inspection of the tubes and defects can be detected as a probe impedance trajectory by moving the coils inside the tube. And higher frequency in this method is needed for the purpose of detecting very small surface cracks in tubes. But it is difficult to test thick ferromagnetic steel tubes using the conventional ECT method. Because test signals of the steel tubes include magnetic noises caused by distribution of initial permeability. Therefore we studied to control the initial permeability and to reduce the magnetic noise using a permanent magnet which magnetize the steel tube on region of less than magnetic saturation point. This ECT probe is differential coils type wound around a columnar permanent magnet. We purposed to make its phenomenon clear by numerical analysis using axisymmetric FEM.
\end{abstract}

キーワード：磁気ノイズ低減、渦電流探傷試験、非線形静磁界解析、交流線形渦電流解析

\section{1. 緒 言}

石油プラント等の熱交換器鋼管の検査は化学プラントの 健全性確保上重要であり、渦電流探傷試験(Eddy Current Testing：ECT)の適用が検討されている。ECTは非接触 で高速に検査できるメリットを持っている。しかし厚肉の 磁性管へのECTの適用は必ずしも適しているとは言えな い。その理由は、材料内の磁気特性の不均一により久陷部 以外からの磁気ノイズが大きく、S/N比が低下するためで ある。磁性管には一般的にリモートフィールド法を用いた ECTが用いられることが多いが、管肉が嬮いことや管の 外㑡にアルミのフィンが付いていることが多いため、適用 できない。また、磁気ノイズの低減には、管を完全に磁気 飽和させて比透磁率を1にする方法も有用であるが、肉厚 が厚く内径の小さい場合に管内側から磁気飽和させること は物理的に不可能である。そこで本研究では、氷久磁石に より材料を管内部より磁化させ、磁気特性のばらつきを抑 えることにより $\mathrm{S} / \mathrm{N}$ 比を向上させるECT手法について数值 解析により検討した。

\section{2. 未飽和領域磁化ECTの解析方法}

\section{$<2 \cdot 1>$ 未飽和磁化ECT解析}

ECTはプローブコイルにより交流磁場を生み出し、材 料中に渦電流を発生させ、コイルのインビーダンスを計測 することにより材料中のき裂を検出する手法である。厚肉 の磁性管のき裂をECTで測定すると、磁性管材料内の透 磁率の不均一により、き裂部分以外からの磁気ノイズが大 きく現れるため、き裂による信号が明確に得られない。そ こで、円筒形の永久磁石をブローブに組み込み、未館和領 域ではあるが、透磁率のぼらつきを低減させ、磁気ノイズ を抑える程度に磁化させ、き裂による信号を鮮明に得られ るECTブローブを提案した。そのブローブの外観図を Fig.1に示す。この現象を解析するには、永久磁石による 静磁場磁化による强磁性体の磁化特性と、ECTコイルに よる交流磁場問題の二つを考慮に入れなくてはならない。 ここでの交流磁場はコイルに流す電流が小さいため、マイ ナーループの特性と考えることができる。そこで数值解析 を行うにあたって、まず強磁性体を静磁場で磁化させた状 
態に交流磁場を加えた時の、强磁性体内の交流透磁率を求 める必要がある。そしてこれを用いて、 ЕСТフローブに 得られる磁気ノイズを解析的に評価することにより、最適 な磁化領域を検討することができる。

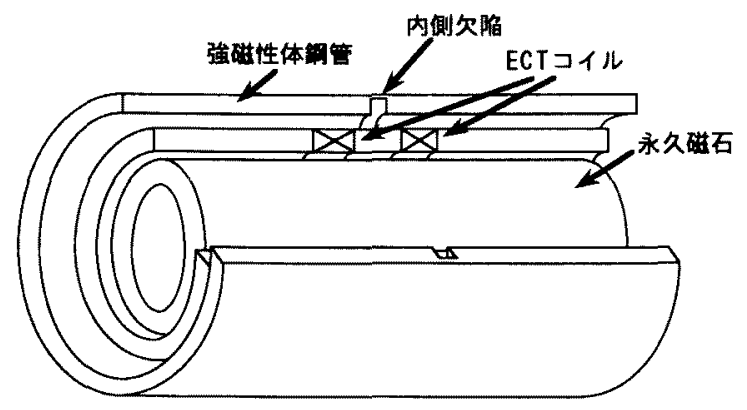

図1 未飽和磁化ECTプローブ

Fig. 1 Model of unsaturated magnetization ECT probe

\section{$<2 \cdot 2>$ 静磁界非線形解析及び}

線形渦電流解析の基本方程式

本研究では、有限要素法による非線形静磁界解析で強磁 性体内の磁束密度を求ぬ、その磁束密度に応じた交流比透 磁率を各要素に与え、交流線形渦電流解析により強磁性体 の磁気ノイズの解析を行う方法を提案する。また、交流比 透磁率江実験と交流線形渦電流解析により求める。解析モ デルは軸対称として取り报う。ここで使用する非線形静磁 界解析及び交流線形渦電流解析の解析方法を以下に示す。

$<2 \cdot 2 \cdot 1>$ 非線形静磁界方程式

非線形静磁界解析の支配方程式はベクトルボテンシャル Aを用いて、

$$
v \cdot \operatorname{rot} \cdot \operatorname{rot} A=J_{o}
$$

と表すことができる。なお、Jo、vは强制電流密度及び、 磁気抵抗率 $\left(v=1 /\left(\mu_{r} \cdot \mu_{0}\right)\right)$ である。本解析で用いる強磁性 体は、等方性磁気材料としている。ここでは軸対称問題を 取り扱うので、非線形静磁界解析に扝ける沉開数 $\chi$ は次式 で表される。

$$
\begin{aligned}
\chi= & \frac{1}{2} \iint_{s} v\left\{\left(\frac{\partial A_{\theta}}{\partial z}\right)^{2}+\left(\frac{A_{\theta}}{r}+\frac{\partial A_{\theta}}{\partial r}\right)^{2}\right\} 2 \pi r d r d z \\
& -\iint_{s} J_{\boldsymbol{O}} A_{\theta} 2 \pi r d r d z
\end{aligned}
$$

この式を変分原理(エネルギー原理)に基づいて、有限要素 法により非線形静磁界解析を行う。强磁性体の磁気特性は、 磁気抵抗率が磁束密度によって变化する非線形特性を示す ことから、磁気抵抗率は磁束密度の関数として表すことが できる。解析では、あらかじ強磁性体の磁化特性 ( $B-H$ 曲線)を磁気抵抗率々磁束密度 $\sigma$ 曲線に変換し、この曲線 に合うよう、(2)式の磁気抵抗率 $v$ を修正し、収束条件を 満たすまで反復計算を行う。本研究の非線形解析における 反復手法及び収束判定法には、ニュートンラプソン法を用 い、非線形反復時の収束判定には、次式を用いた。

$$
\left|\left(\sum A^{(k)}-\sum A^{(k+1)}\right) / \sum A^{(k+1)}\right|^{<\varepsilon}
$$

ここで、 $\Sigma A^{(k)} 、 \sum A^{(k+1)}$ はそれぞれ、 $\mathrm{k}$ 及び $\mathrm{k}+1$ 回目のポ テンシャルの総和であり、とは收束判定值である。本解析 では、 $\varepsilon$ をり小さい值にしても得られる解に変化が見ら れないことを確認したうえで $1.0 \times 10^{-5}$ とした。本解析では 軸対称有限要素法を使用し、要素は4節点1次アイソパラ メトリック要素を用いた。

\section{$<2 \cdot 2 \cdot 2>$ 線形渦電流解析方程式}

交流線形瀜電流解析の支配方程式は次式で表せる。 $\operatorname{rot}(\boldsymbol{v} \cdot \operatorname{rot} \boldsymbol{A})=J_{o}-J_{e}$

ここでJeは、渦電流密度 $J_{e}=-j \omega \sigma A$ である。また、 $\sigma 、 \omega$ は導䨘率及び、觕周波数である。軸対称モデルの交流磁場 に扝ける沉関数 $\chi$ は次式で表される。

$$
\begin{aligned}
\chi= & \frac{1}{2} \iint_{s} v\left\{\left(\frac{\partial A_{\theta}}{\partial z}\right)^{2}+\left(\frac{A_{\theta}}{r}+\frac{\partial A_{\theta}}{\partial r}\right)^{2}\right\} 2 \pi r d r d z \\
& -\iint_{s}\left(J_{S} \theta-\frac{1}{2} J \omega \sigma A_{\theta}\right) A_{\theta} 2 \pi r d r d z
\end{aligned}
$$

この式を変分原理(エネルギー原理)に基ゔいて、有限要素 法により交流線形渦電流解析を行う。軸対称有限要素法に よる交流線形滑電流解析では、ECTプローブコイル部の ベクトルポテンシャルを用い、周回積分を行うことにより コイルのインピーダンスを算出することができる。

$$
z=\frac{-j \omega N_{t} \oint_{C} A_{c} d l}{I}
$$

ここでの $N_{t} 、 \boldsymbol{A}_{c} 、 I$ はそれぞれコイルの巻数、コイル 部 のベクトルボテンシャル、強制電流である。

\section{3. 交流磁気特性の測定}

本研究では、実験及び数值解析により交流磁場に扔ける 磁気特性を求めた。交流比透磁率测定モデルをFig.2に示 す。これは実際に石油化学ブラントの熱交換器で使用され ている強磁性体鍼管(材質: STB35)の外側に励磁コイル (1600ターン)を巻き、管内にECTブローブのコイルを洀 入した構造である。交流磁気特性測定の手順を示したフロ一 チャート図をFig.3に示す。また、Fig.4に強磁性体 (STB35)の磁化曲線を示す。亦ず值流電流で外側より鋼管 を磁化させ、励磁電流に応じたインピーダンスをECTブ ローブで測定する。次に、磁気べクトルポテンシャルによ る非線形静磁界解析により、この励磁電流に㐫した管内の

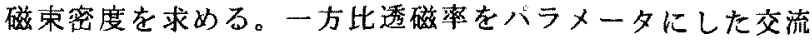
線形渦電流解析により、コイルのインビーダンスを求める。 この結果と実験により得られたインビーダンスから強磁性 体内の交流比透磁率を導きだし、またその時の磁束密度と で交流磁場における磁気特性( $B-\mu_{r}$ 曲線)を求めた。本実 験ではECTブローブに加える周波数は300kHzで行った。 
この方法により得られた結果をFig.5に示す。

\section{4. 数值解析によるノイズ評価}

本研究では、交流磁化曲線(Fig.5)を使用し、ECTブロー ブによる磁気ノイズを求めた。

\section{$<4 \cdot 1>$ 磁気ノイズ解析手順}

本研究の磁気ノイズ解析手順を示したフローチャート図 をFig.6に示す。磁気ノイズを求めるには、まず強磁性体 内の各要素にランダムに磁気特性分布を与え、初期透磁率 のばらつきを与える。次に、永久磁石による蹎流磁化にお ける强磁性体内の磁束密度分布を非線形静磁界解析により 求め、その磁束密度分布から実騟及び解析により求めた交 流磁気特性(Fig.5)を使用して、強磁性体内の交流の比透 磁率分布を導きだす。その交流比透磁率分布を基にして交 流線形渦電流解析を行い、磁気ノイズの評価を行う。

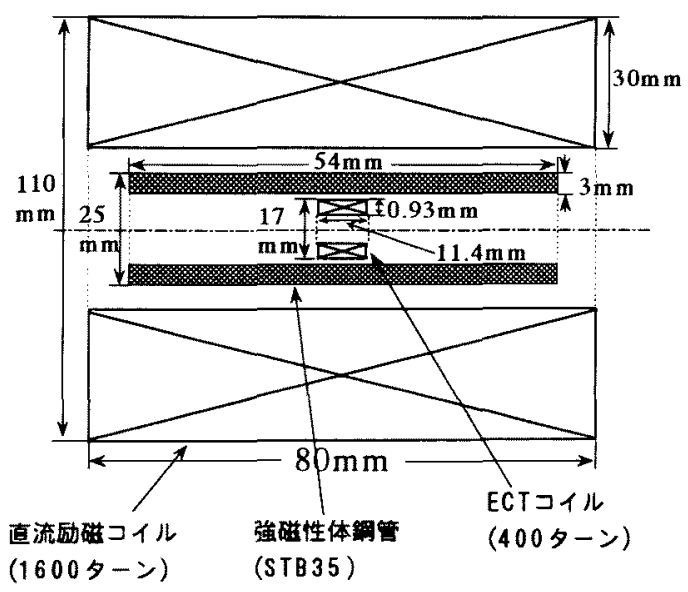

図2 交流比透磁率測定モデル

Fig.2 Measurement equipment of alternating permeability

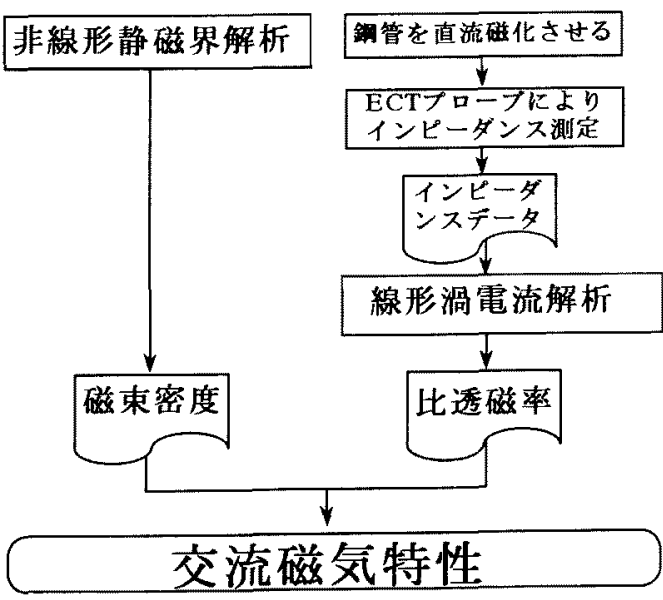

図 3 交流磁気特性の測定手順

Fig. 3 Flow chart of alternating magnetization curve measurement

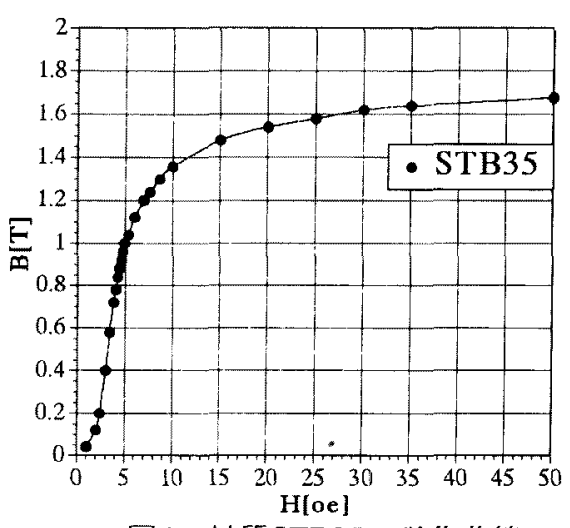

図4 材質STB350磁化曲線

Fig.4 B-H curve of STB35

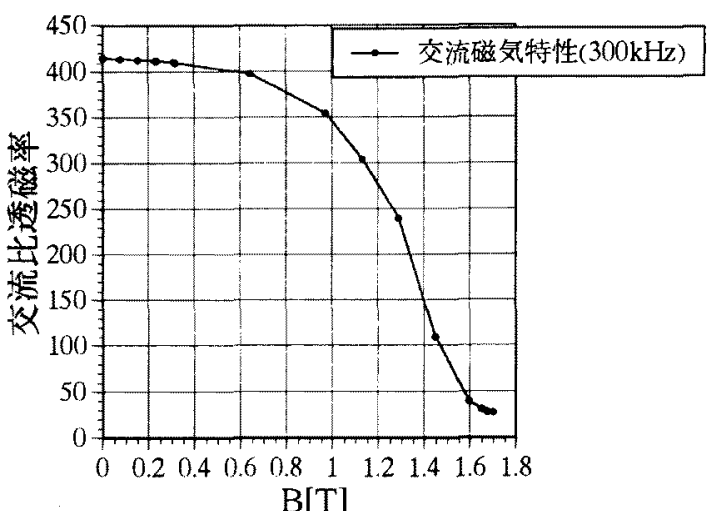

网5 交流磁気特性（B- $\mu \mathrm{r}$ 曲線）

Fig.5 B- $\mu$ r curve for alternating magnetic flux

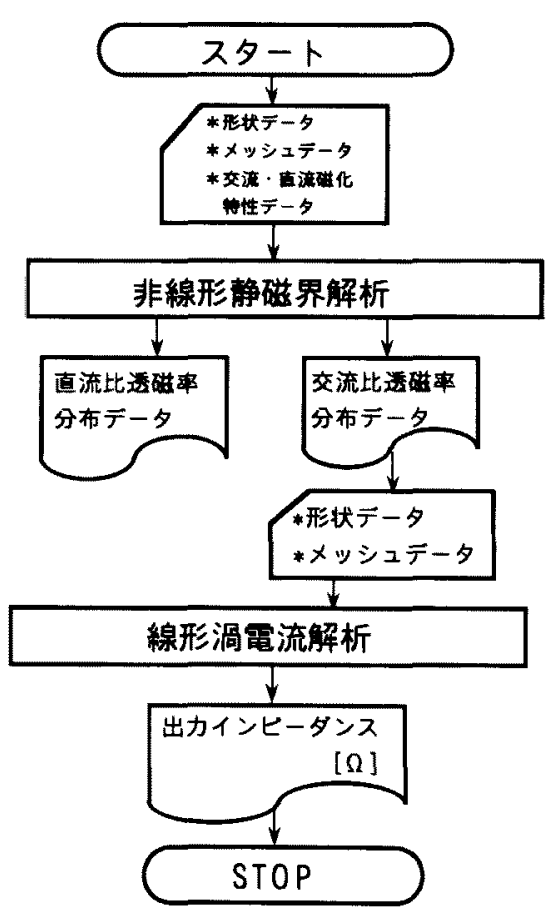

図 6 磁気ノイス解析フローチャート

Fig.6 Flow chart of magnetic noise analysis 


\section{$<4 \cdot 2>$ 解析モデル}

実機検査に適応可能な検査ブローブの検討を行った。実 際の熱交換器鋼管の検查には、その構造的制約から鋼管内 側からしか検査出来ない。また管内を通すプローブは鋼管 内径より、プローブの最大径が限定される。さらにこの鋼 管は肉厚が厚いため、内部から完全に磁気飽和させるのは 不可能である。そこで、プローブ内部に永久磁石を組み込 み、未飽和領域となるが鋼管内側を磁化させ、磁気ノイズ 低減を検討した。本研究での解析モデル図をFig.7に示す。 このモデルに対して軸対称解析を行った。これは、円筒形 の永久磁石の周りにECTコイルを差動形に巻いた構造で ある。被検材である強磁性体は、実際の石油化学ブラント 内の熱交換器鋼管に使用されている材質(STB35) とした。 長さは $220 \mathrm{~mm}$ 、厚さ $4.4 \mathrm{~mm}$ 、導電率は $6.333 \times 10^{6} \mathrm{~S} / \mathrm{m}$ であ る。また、材料内の初期透磁率のばらつきは評価出来ない ため、直流磁化による初期比透磁率を最大比透磁率 (2000)の10〜25\%程度とし、各要素にランダムにその磁 気特性を与えた。被㭘材を磁化させる永久磁石は、解析上 直流磁化電流で模擬し、長さは $12 \mathrm{~mm}$ で、外半径 $11 \mathrm{~mm}$ 、

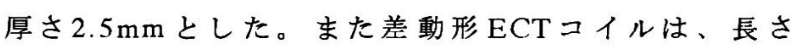
$2.0 \mathrm{~mm}$ 、外半径 $15 \mathrm{~mm}$ 、厚さ $2.5 \mathrm{~mm}$ で、コイル巻数は各 160 ターンである。また、周波数は $300 \mathrm{kHz}$ 一定とした。 この永久磁石と差動形ブローブコイルを同時に移動させて 解析を行った。このプローブコイルのインビーダンス変化 により直流磁化された強磁性体の磁気ノイズ評価を行う。

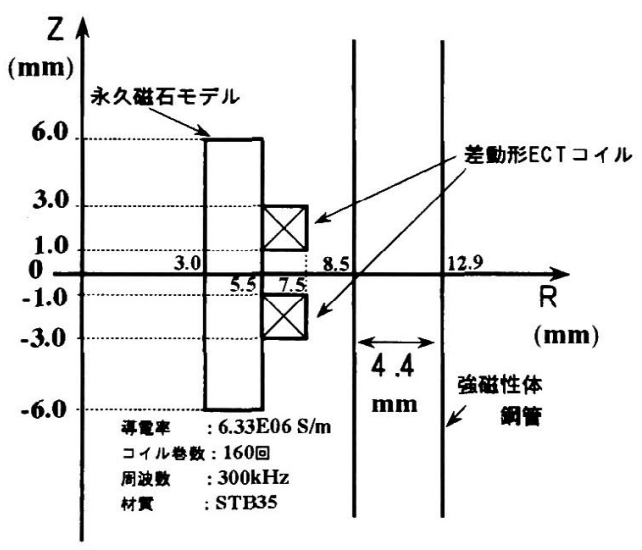

図7 解析モデル

Fig.7 Model of numerical analysis

$<4 \cdot 3>$ 磁気ノイズ解析結果及び考察

永久磁石の残留磁気值を0.0、0.5、0.8、1.1 T と变化さ せた時の強磁性体内部の交流比透磁率分布をFig.8に示す。 残留磁気值が0.0 T 時では、比透磁率のばらつきが大きい ことがわかる。残留磁気值を0.5、0.8 T と增加させるにつ れ、比透磁率のばらつき分布が小さくなっていることが理 解できる。さらに $1.1 \mathrm{~T}$ 時まで増加すると、ほぼ永久磁石 の中心部付近の強磁性体内部より磁化分布が均一になって 抢り、交流比透磁率は減少傾向を示していることが理解で きる。また、交流比透磁率分布は永久磁石の残留磁気值の 増加に伴い、永久磁石中心部付近からムラがなくなること が理解できる。

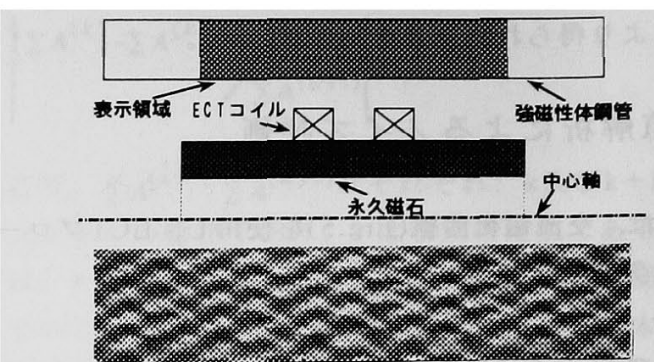

(a) 永久磁石の残留磁気值 OT時の

強磁性体内の交流比透磁率分布

（最大值：416、最小值 : 414)

(b) 永久磁石の残留磁気值 $0.5 \mathrm{~T}$ 時の

強磁性体内の交流比透磁率分布

(最大值 : 415.1、最小值 : 413.8)

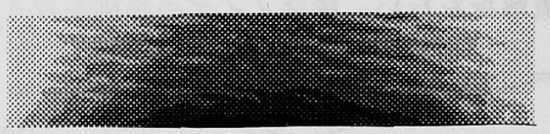

(c) 永久磁石の残留磁気值 $0.8 \mathrm{~T}$ 時の

強磁性体内の交流比透磁率分布

(最大值 : 415.5、最小值 : 413)

(d) 永久磁石の残留磁気值 $1.1 \mathrm{~T}$ 時の

強磁性体内の交流比透磁率分布

(最大値 : 415.5、最小値 : 412)

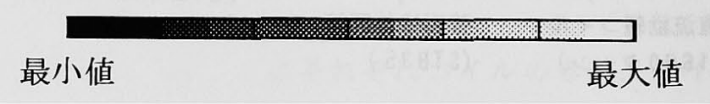

図8 永久磁石の残留磁気值をパラメータ にした強磁性体内の交流比透磁率分布

Fig.8 Distribution change of alternating permeability in material

\section{5. き裂信号解析}

実機検査に適応可能な永久磁石を検討した。内径が $17 \mathrm{~mm}$ 强磁性体鋼管内に挿入するプローブ内部に設置す る永久磁石の残留磁気值を考慮すると、物理的に約 $1.0 \mathrm{~T}$ を大幅に越える水久磁石の使用は現実的ではないことから、 き裂信号解析に使用する永久磁石の残留磁気值は $1.1 \mathrm{~T}$ 一 定として解析を行った。

\section{$<5 \cdot 1>$ き裂信号解析モデル}

解析モデルはFig.7を使用した。ECTブローブの周波数 は300k Hzより、鋼管内側のき裂検出の検討を日的として いるため、き裂モデルは鋼管内側に想定し、管厚に対して $40 \%$ 深さとした。き裂幅を1、2、3 m の解析を行った。

$<5 \cdot 2>$ き裂信号解析結果及び考察

き裂幅を変化させた時の強磁性体内の交流比透磁率分布 
変化の解析結果をFig.9に示す。き裂が存在しない時は、 鋼管内側の比透磁率分布は均一であるのに対し、き裂の存 在により比透磁率分布の乱れが現れていることが理解出来 る。また、き裂幅が増えるに伴いその乱れは大きく、特に き裂のエッジ部に大きな変化が現れていることが分かる。 この時のき裂信号 (レジスタンス成分、リアクタンス成分) 及び、リサージュ波形をFig.10に示す。き裂幅が大きくな るにつれて、それぞれの振幅は大きくなることが理解出来 る。またりサージュ波形より、き裂の幅変化による位相差 が現れていることも合わせて理解できる。

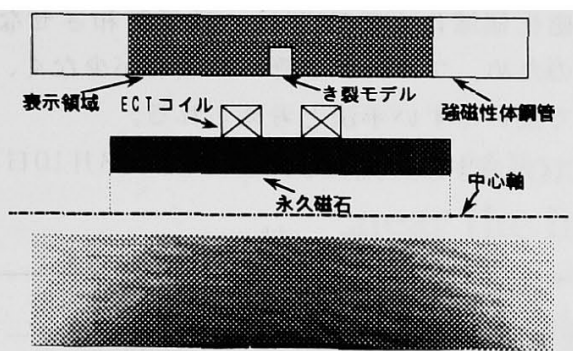

(a) 強磁性体内の交流比透磁率分布 (最大值 : 415.5、最小值 : 412)

（b）き裂幅 $1 \mathrm{~mm}$ 時の強磁性体内の交流比透磁率分布 (最大值：416、最小值 : 400)

(c) き裂幅 $2 \mathrm{~mm}$ 時の強磁性体内の交流比透磁率分布 (最大值：416、最小值 : 404)

(d) き裂幅 $4 \mathrm{~mm}$ 時の強磁性体内の交流比透磁率分布 (最大值：416、最小値：406)

$$
\text { 最小值 }
$$

図9き裂幅変化による交流比透磁率分布 (永久磁石の残留磁気値1.1T一定)

Fig.9 Distribution of alternating permeability near crack in material (Remanence of permanent magnet:1.1T)

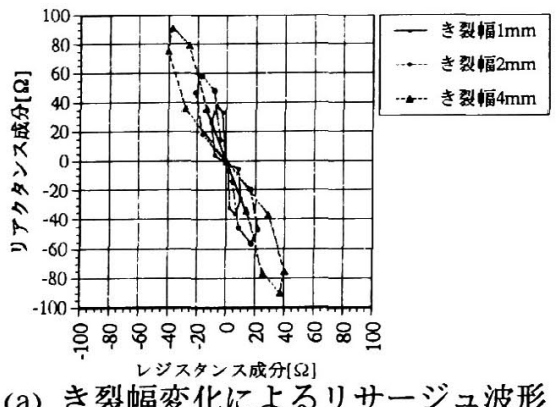

(周波数 $300 \mathrm{kHz}$ )

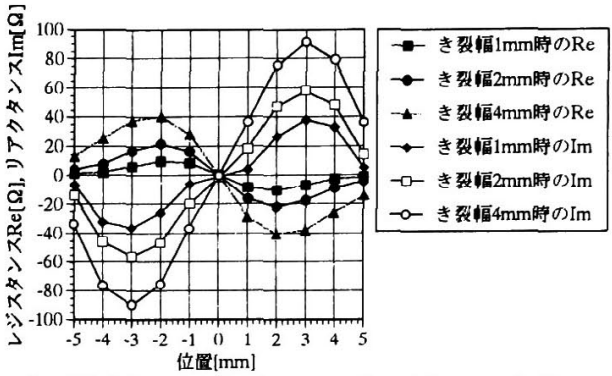

(b) き裂幅変化によるインピーダンス変化

図10 き裂幅変化によるECT信号

Fig.10 ECT signal of change crack width

\section{6 ．実験による検討}

実機検査に適応可能な検查ブローブの作成及び、実験を 行った。実験に用いた検査ブローブは通常ECTブローブ 及び、残留磁気值1.1 T の永久磁石を挿入したECTブロー ブの 2 種類である。これらのブローブの寸法をFig.11に、 実験装置の外観図をFig.12に示す。なお、ECTコイルの 巻数、周波数、強磁性体材料等は解析時のものと同じにし た(Fig.7)。また、検査したき裂の大きさは、径がそれぞ れ3 及及び $5 \phi \sigma$ 貫通き裂の 2 種類のものとした。実験に より得りれたき裂信号（リアクタンス成分、レジスタンス 成分）をそれぞれFig.13に示す。通常ECTフローブによ る探傷結果は、5 5 の貫通き裂のレジスタンス成分は大き く検出できてはいるが、3 3 の貫通き裂のレジスタンス成 分は、き裂部以外の磁気ノイズと同じ振幅のため見分けが つきにくくなっている。また、き裂信号のリアクタンス成 分に関しては、磁気ノイズの振幅が大きく現われているた め、どれがき裂信号の振幅なのか全く見当がつかない結果 となっている。これに対して残留磁気值1.1 T の)永久磁石 を挿入したECTブローブによる探傷結果ではリアクタン ス成分、レジスタンス成分共に、き裂部以外の磁気ノイズ を低減させ、き裂信号の振幅を大きく表していることが理 解できる。

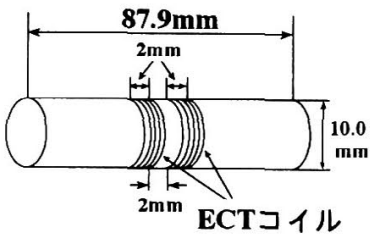

(a) 通常ECTプロープ

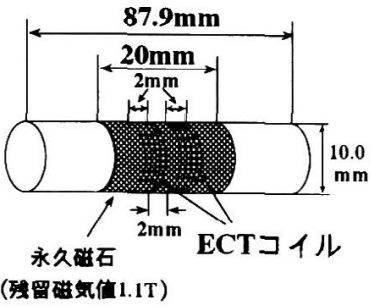

（b）未飽和磁化ECTプローフ

図11通常ECTと未飽和磁化ECTプローブ

Fig.11 Model of normal ECT probe and unsaturated magnetization ECT probe 


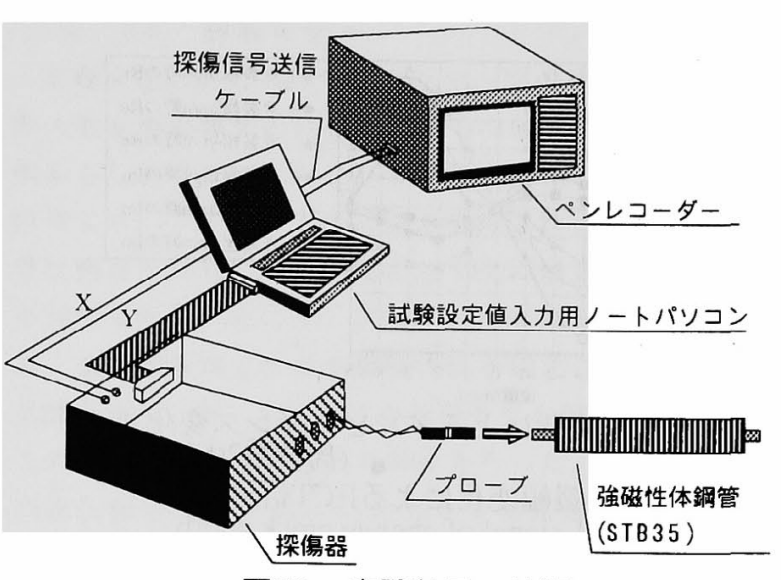

図12 実験装置の外観図

Fig.12 Model of verification experiment

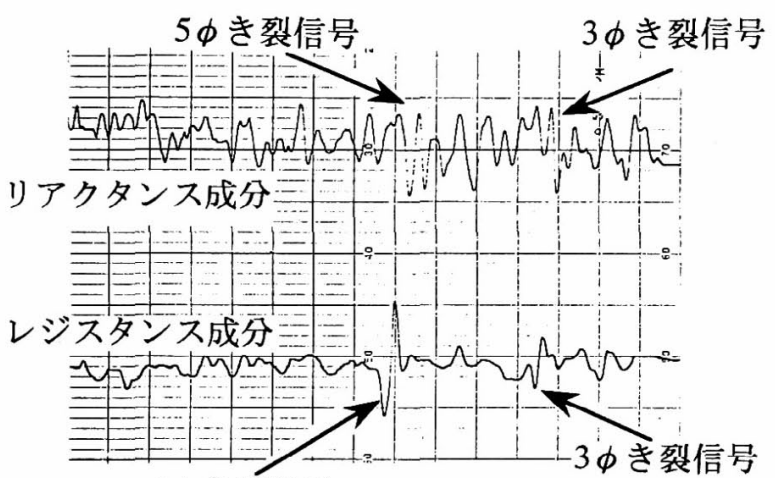

$5 \phi$ 裂信号

(a) 通常ECTプローブによる実験波形 (周波数 : $300 \mathrm{kHz}$ ，き裂 : $3 \phi, 5 \phi$ 貫通)

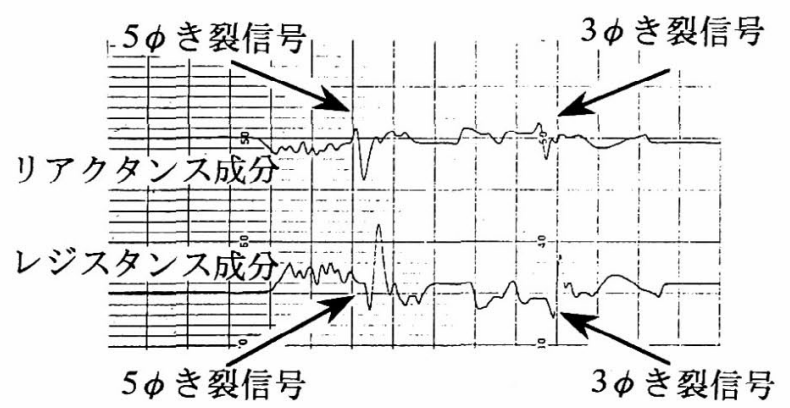

（b）末飽和磁化ECTプローブによる実験波形 (周波数: $300 \mathrm{kHz}$,き裂: $3 \phi, 5 \phi$ 貫通)

図13 通常ECTと未飽和磁化ECTプローブ

Fig.13 Crack signal of normal ECT and との比較 unsaturated magnetization ECT

\section{7.まとめ}

磁性管ECT 未飽和領域磁化によるノイズ低減数值解析 による評価を行った。得られた結果を以下に示す。

(1)强磁性体内の交流磁場による磁化特性を求めた。

(2)強磁性体を磁化させた時の交流比透磁率分布を求的、 磁気ノイズ評価を解析的に示すことができた。

(3)実験及び解析により、未飽和磁化領域によるECTの 有用性を示した。

未飽和磁化領域によるECTは、磁気飽和させない程度 の磁化力のため、プローブの管への吸着が少なく、実際の 検査作業で扱いやすい手法と考えりれる。

(平成9年1月20日受付、平成9年3月10日再受付)

$$
\text { 文献 }
$$

[1] 後藤雄治、福冨宏幸、橋本光男: 弱磁化プローブに よる厚肉鋼管の内面検査法の評価、日本非破壊検査 協会、平成 7 年度春季大会、pp. 191-194

[2] 後藤雄治、福冨宏幸、佐藤宏、橋本光男: 弱磁化に よる磁性管ECT のノイズ低減、The Fourth MAGDA Conference in Tottori, pp. 193-196(1995)

[3] Y.Goto, M. Hashimoto: Magnetic Noise Reduction for ECT of Thick Steel Tube by Unsaturated Magnetization, The First US-Japan Symposium on Advances in NDT, pp.265-268(1996)

[4] 後藤雄治、橋本光男: 磁性管ECT 0 来飽和領域磁化 によるノイズ低減数值解析、電気学会、平成 8 年マ グネティックス研究会、pp.165-169

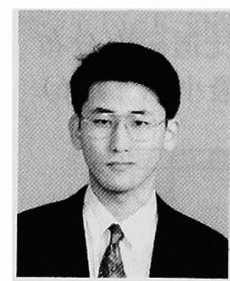

後藤雄治（学生員）1972年 5 月28日生 まれ。1996年3月職業能力開発大学校電気 工学科卒業。同年 4月職業能力開発大学校 研究課程工学研究科電気・情報専攻入学、 現在に至る。電磁現象を応用した強磁性体 の非破壊検査に関する研究に従事。電気学 会、日本AEM学会、日本非破壊検查協会 学生会員。

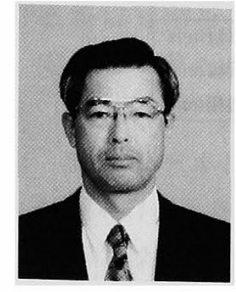

橋本光男（正員）1950年12月11日生ま れ。1972年茨城大学工業短期大学部電気 工学科卒業。1976年同電子工学科卒業。 1971年東京大学工学部、文部技官、助手。 1990年職業能力開発大学校電気工学科助 教授。1995年同教授、現在に至る。工学 博士。電磁気を応用した非破壊評価に関す る研究に従事。電気学会、日本AEM学会、 日本非破壊検査協会会員。 